\title{
Desulfurization of Gasoline and Diesel by Adsorption with $\mathrm{Cu}(\mathrm{I})-\mathrm{Y}$ Zeolite
}

\author{
Kuen-Song LIN, Abhijit Krishna ADHIKARI \\ and Ze-Ping WANG \\ Department of Chemical Engineering and Materials Science/Fuel Cell \\ Center, Yuan Ze University, Chung-Li City, Taiwan 320, R.O.C.
}

Keywords: Desulfurization, Gasoline, Diesel, Y Zeolite, $\pi$-Complexation, Adsorption

\begin{abstract}
The objectives of this work were to fabricate $\mathrm{Cu}(\mathrm{I})-\mathrm{Y}$ zeolite nanoparticles for the delsulfurization of commercial gasoline and diesel using fixed-bed adsorption processes at room temperature. The $\mathrm{Cu}(\mathrm{I})-\mathrm{Y}$ zeolite prepared in the present study showed that the breakthrough capacities of 21 and $9 \mathrm{mg} / \mathrm{g}$ of adsorbents of diesel and gasoline, respectively at $298 \mathrm{~K}$ for sulfur removal. Under the same experimental conditions, the saturation loadings were 36 and $23 \mathrm{mg} / \mathrm{g}$ for diesel and gasoline, respectively. Moreover, the structural morphology, crystallinity, fine structure and characteristics of the adsorbents were also systematically investigated. TPR profile of $\mathrm{Cu}(\mathrm{II})-\mathrm{Y}$ zeolite indicated that the two reduction steps at 462 and $509 \mathrm{~K}$, respectively were observed. A reduction temperature of about $462 \mathrm{~K}$ is sufficient to obtain the cuprous species required for $\pi$-complexation. EXAFS spectra showed that the bond distances of $\mathrm{Cu}-\mathrm{S}$ in $\mathrm{Cu}_{2} \mathrm{~S}$ and $\mathrm{CuS}$ were 2.35 and $2.47 \AA$, respectively in the sulfur-adsorbed $\mathrm{Cu}-\mathrm{Y}$ adsorbent.
\end{abstract}

\section{Introduction}

Deep desulfurization of commercial gasoline and diesel fuels (CGDFs) has become an important topic due to the upcoming legislative regulations to reduce sulfur content all over the world. These liquid fuels contain various organic-sulfur compounds, which not only contribute to air pollution, but also cause serious hazardous impact on environmental risk and safety. Consequently, the sulfur level in CGDFs must be reduced from current maximum 500 to $15 \mathrm{ppmw}$ in the USA and to $10 \mathrm{ppmw}$ in the EU by 2010 (Kim et al., 2006). Further lower limitation of sulfur or sulfur free CGDFs are required for the near future. Moreover, CGDFs are considered as potential liquid fuels for portable fuel cell (FC) system and automobiles due to their ready availability, proven safety for easily delivery or storage, and higher energy density. However, the levels of organic sulfur present in CGDFs and the generated $\mathrm{H}_{2} \mathrm{~S}$ from them during reforming process are sufficient to significantly reduce the activity and lifetime of catalysts as well as electrode catalysts for a FC processor. It is generally agreed that the sulfur concentration in CGDFs has to be reduced to less than $0.1 \mathrm{ppmv}$ for fuel cell applications (Song, 2003; Kim et al., 2006; Xue et al., 2006).

The removal of sulfur containing compounds present in gasoline and diesel fuels is an important op-

Received on July 12, 2008; accepted on July 12, 2009. Correspondence concerning this article should be addressed to K.-S. Lin (Email address: kslin@saturn.yzu.edu.tw ).

Presented at ISCRE 20 in Kyoto, September, 2008. eration in the petroleum refinery. Industrially, majority of sulfur is eliminated through the hydrodesulfurization (HDS) process (Babich and Moulijn, 2003). HDS uses $\mathrm{Co}-\mathrm{Mo} / \mathrm{Al}_{2} \mathrm{O}_{3}, \mathrm{Ni}-\mathrm{Mo} / \mathrm{Al}_{2} \mathrm{O}_{3}$ or Ni-W/Al ${ }_{2} \mathrm{O}_{3}$ catalysts. This process has also some disadvantages such as the catalytic processes operated at elevated temperatures $\left(300-400^{\circ} \mathrm{C}\right)$ and elevated pressures $\left(20-100 \mathrm{~atm}\right.$ of $\left.\mathrm{H}_{2}\right)$. Moreover, HDS process is highly efficient for the removal of sulfur compounds such as thiols, sulfides and thiophenes, but less effective for removing thiophene derivatives: benzothiophene (BT), dibenzothiophene (DBT), and their alkyl derived as 4-methyldibenzothiophene (MDBT) which are abundant especially in diesel and can lead the sulfur concentration up to 400 ppmw (Schulz et al., 1999; Baeza et al., 2008; García-Gutiérrez et al., 2008).

At present, several alternative approaches have been tested, such as selective adsorption, bio-desulfurization, oxidative desulfurization, and extraction by ionic liquid (Song, 2003; Hernández-Maldonadoa et al., 2005a, 2005b; Bhandari et al., 2006; Caero et al., 2006; AlShahrani et al., 2007). Adsorptive desulfurization is a new and highly efficient method for this purpose and also a widely used technology, due to its simplicity and adaptability to different fuel processors. In addition, it can be accomplished relatively at lower pressure and temperature even at ambient conditions (Tang et al., 2008). A distinguished amount of adsorbents have been reported for the removal of sulfur compounds from the CGDFs. Many works have focused on the porous materials such as charcoal (Mikhail et al., 2002), mesoporous SBA-15, 
adsorbents based on transition metal complex supported on porous materials (zeolites) (Salem, 1994; HernándezMaldonado and Yang, 2003; Velu et al., 2003; Yang et al., 2003; Hernández-Maldonadoa et al., 2005a; Ma et al., 2005), or transition metals, on mixed metal oxides, on activated carbon (AC), and transition metal compound supported on a porous silica gel (Ma et al., 2002). Several works have developed new adsorbents to remove the thiophenic compounds from CGDFs via $\pi$-complexation, most of them published by Yang and collaborators (Velu et al., 2003; Yang et al. 2003; Hernández-Maldonadoa et al., 2005a). The $\pi$-complexation adsorption is currently the most promising alternative. Molecular orbital (MO) calculations and experiments have shown that the refractory compounds (MDBT and DMDBT) bind strongly through the $\pi$-complexation due to a better electron donation/back-donation ability. In the $\pi$ complexation mechanism the cations can form the usual $\sigma$ bonds with their $s$-orbitals while their $d$-orbitals can back-donate electron density to the antibonding $\pi$ orbitals of the sulfur rings. The metals that can form strong $\pi$-complexation bonding are those that possess empty $s$-orbitals and the electron density available at the $d$-orbitals necessary for back donation. Some literatures reported that $\pi$-complexation ion-exchanged $\mathrm{Y}$ zeolite sorbents obtained with $\mathrm{Cu}(\mathrm{I}), \mathrm{Ni}(\mathrm{II})$ or $\mathrm{Zn}(\mathrm{II})$ cations using different techniques have been studied for their usefulness in desulfurization of diesel, especially the copper $\mathrm{Cu}(\mathrm{I})$ for its electronic configuration $1 \mathrm{~s}^{2} 2 \mathrm{~s}^{2} 2 \mathrm{p}^{6} 3 \mathrm{~s}^{2} 3 \mathrm{p}^{6} 3 \mathrm{~d}^{10} 4 \mathrm{~s}^{0}$ (Hernández-Maldonadoa et al., $2005 b)$. These sorbents desulfurization performance decreased as following: $\mathrm{Cu}(\mathrm{I})-\mathrm{Y}>\mathrm{Ni}(\mathrm{II})-\mathrm{Y}>\mathrm{Zn}$ (II)$\mathrm{X}>\mathrm{Zn}(\mathrm{II})-\mathrm{Y}$. Molecular orbital calculations also indicated that these sorbents performance decreased as following: $\mathrm{Cu}(\mathrm{I})>\mathrm{Ni}(\mathrm{II})>\mathrm{Zn}(\mathrm{II})$ (Hernández-Maldonadoa et al., 2005b). Therefore, the main objective was to investigate the desulfurization of commercial gasoline (76 ppmw S) and diesel (49 ppmw S) by $\pi$-complexation ionexchanged adsorbents of $\mathrm{Cu}(\mathrm{I})-\mathrm{Y}$ zeolite in a fixed-bed adsorber. Morphologies, crystallinity, and microstructures of this $\mathrm{Cu}(\mathrm{I})$ sorbent was also identified and characterized by TPR, $\mathrm{N}_{2}$ adsorption isotherms (BET surface area), FE-SEM/TEM, XRD, Elemental Analyzer (EA), and X-ray absorption near edge structure/extended X-ray adsorption fine structure (XANES/EXAFS) techniques.

\section{Experimental}

\subsection{Sorbents preparation}

The sorbents used in the present work were nanophase $\mathrm{H}-\mathrm{Y}$ zeolite particles $(\mathrm{Si} / \mathrm{Al}=10$; surface area $=640 \mathrm{~m}^{2} / \mathrm{g}$; total pore volume $=0.318 \mathrm{~cm}^{3} / \mathrm{g}$; framework density $=1.25 \mathrm{~g} / \mathrm{cm}^{3}$ ). The framework structures of $\mathrm{Y}$ zeolites are characterized by the double 6ring (D6R). The pore of zeolite $\mathrm{Y}$ that is restricted by 12-membered oxygen rings (Wang et al., 1999). Zeolites $\mathrm{Y}$ has a three-dimensional channel structures with pore sizes of 7.4-8.1 and therefore useful as adsorbents for relatively large molecules such as gasoline and diesel. The zeolites were modified by liquid phase ion exchange (LPIE) technique (Bhandari et al., 2006) and $\pi$ complexation $[\mathrm{Cu}(\mathrm{I})-\mathrm{Y}]$ zeolite was prepared with $0.5 \mathrm{M}$ $\mathrm{Cu}\left(\mathrm{NO}_{3}\right)_{2(a q)}$ for $48 \mathrm{~h}$ followed by reduction of $\mathrm{Cu}(\mathrm{II})$ to $\mathrm{Cu}(\mathrm{I})$. A typical ion exchange procedure of $\mathrm{H}-\mathrm{Y}$ with $\mathrm{Cu}\left(\mathrm{NO}_{3}\right)_{2(a q)}$ was carried out at $298 \mathrm{~K}$ and at $\mathrm{pH} 5$ for 9$10 \mathrm{~h}$. The ion exchange process was repeated two times, each time for a period of $3 \mathrm{~h}$ to ensure desired level of ion exchange. The amount of copper in the ion exchange solution was equivalent to a 5-fold cation exchange capacity. After the ion exchange, the $\mathrm{H}-\mathrm{Y}$ zeolite sorbents were filtrated, washed with deionized water to remove the excess solution, and then dried at $373 \mathrm{~K}$ for over $24 \mathrm{~h}$. The average copper concentration over the $\mathrm{H}-\mathrm{Y}$ zeolite was around $3 \mathrm{wt} \%$ identified using ICP/MS method. Autoreduction of $\mathrm{Cu}(\mathrm{II})$ to $\mathrm{Cu}(\mathrm{I})$ was also conducted under a flowing inert He gas at $723 \mathrm{~K}$ for over $18 \mathrm{~h}$ (HernándezMaldonadoa and Yang, 2003; Hernández-Maldonadoa et al., 2005b; Yang et al., 2001, 2003). The $\mathrm{Cu}(\mathrm{I}) / \mathrm{Cu}(\mathrm{II})$ ratio in the activated $\mathrm{Cu}-\mathrm{Y}$ zeolite sorbent was ranged of 0.5-0.7 measured by $\mathrm{Cu} \mathrm{K}$-edge XANES techniques. A quartz-tube furnace was used for activating the $\mathrm{H}-\mathrm{Y}$ zeolite adsorbents under well controlled conditions. After activation, the adsorbents were cooled down to room temperature under a flowing He gas. All the adsorbents were carefully activated in order to avoid any exposure to moisture. For $\mathrm{Cu}$ zeolites, this step is critical since $\mathrm{Cu}(\mathrm{I})$ species are highly unstable. Since Y zeolite adsorbent is recognized to be highly hydrophilic (water uptake $>20 \mathrm{wt} \%$ at ambient conditions), helium gas was initially passed through a $3 \mathrm{~A}$ molecular sieve column to remove moisture before use. The unit cell composition for the dehydrated $\mathrm{H}-\mathrm{Y}$ zeolite sorbents prepared using LPIE methods is $\mathrm{Cu}_{21} \mathrm{Na}_{14}\left(\mathrm{~A}_{l 56} \mathrm{Si}_{136} \mathrm{O}_{384}\right)$ (Wang et al., 1999; Hernández-Maldonadoa et al., 2005b).

\subsection{Fixed-bed adsorption/breakthrough}

All adsorption/breakthrough experiments were conducted in a vertical quartz adsorber equipped with a supporting glass frit. The setup consisted of a low-flow liquid pump, Kynar and Teflon compression fittings, feed tanks, and a heating jacket. About $2.0 \mathrm{~g} \mathrm{H}-\mathrm{Y}$ zeolite sorbent was loaded inside the adsorber tube with a diameter of $5 \mathrm{~mm}$ (I.D.) and a length of $10 \mathrm{~cm}$. The sorbents were heated at $723 \mathrm{~K}$ and then cooled down to room temperature under a flowing He gas. A sulfur-free hydrocarbon was flowing through the sorbents for $10 \mathrm{~min}$ to order to wet and clean the adsorbed bed previously. Finally, the feed was switched to CGDFs at a flow rate of $0.5 \mathrm{~mL} / \mathrm{min}$. Effluent liquids were collected until the saturation point was achieved. The typical compositions of CGDFs are shown in Table 1.

\subsection{Characterization methods}

All the CGDFs samples collected during breakthrough experiments were analyzed using gas chromatography/flame photometric detection (GC/FPD, 6890N 
with FPD, Aligent Technologies Inc.) with an EC-5 capillary column (I.D. $=0.32 \mathrm{~mm} ; L=30 \mathrm{~m}$ ). The average concentration of $\mathrm{Cu}$ species in $\mathrm{H}-\mathrm{Y}$ zeolite sorbents was measured by ICP/MS (Perkin-Elmer SCIEX-ELAN 6100 DRC, PerkinElmer Inc.). The concentrations of $\mathrm{Cu}$ ions were calculated after calibrating individual measured curve by its corresponding standard $\mathrm{Cu}$ solution at ten different concentrations. The surface area of the as-synthesized $\mathrm{Cu}(\mathrm{I})-\mathrm{Y}$ zeolite was measured using BET (Brunauer-Emmett-Teller) nitrogen adsorption method (ASAP Micromeritics 2010 Instrument). A conventional temperature programmed reduction (TPR) apparatus was used for the investigation of the reducibility of the $\mathrm{Cu}$ catalysts. TPR measurement was conducted using a flow rate of $30 \mathrm{~mL} / \mathrm{min}$ of $\mathrm{H}_{2} / \mathrm{Ar}$ mixture $\left(30 \mathrm{vol} \% \mathrm{H}_{2}\right)$ at 1 atm. $0.5 \mathrm{~g}$ of catalyst samples was tested each time and a heating rate of $10 \mathrm{~K} / \mathrm{min}$ was performed from 298 to 800 K. Proximate and ultimate analyses of $\mathrm{Cu}(\mathrm{I})-\mathrm{Y}$ zeolite were performed using traditional elemental analyzer (EA, F002-heraeus CHN-O rapid) as a tool. The morphologies, crystallinity, and microstructures of $\mathrm{Cu}(\mathrm{I})-\mathrm{Y}$ zeolite was determined by FE-SEM/EDS (S-4700 Type II, Hitachi Ltd.). In addition, catalyst samples were dispersed on a carbon film supported by a copper grid for TEM (Model Zeiss 10C) observation. Structural investigations of the as-prepared products were carried out in a transmission electron microscope working at $200 \mathrm{kV}$. With regard to the identification of the solid phases and crystallinities of $\mathrm{Cu}(\mathrm{I})-\mathrm{Y}$ zeolite, $\mathrm{XRD}$ was performed (MXP18, MAC Science Co. Ltd.). The sample was therefore scanned from 20 to $60^{\circ}(2 \theta)$ with a scan rate of $4^{\circ}(2 \theta) / \mathrm{min}$ and monochromatic $\mathrm{CuK}_{\alpha}$ radiation. The specific peak intensities and $2 \theta$ values recorded can be further identified by a computer database system (Joint Committee on Powder Diffraction Standards, JCPDS of International Centre for Diffraction Data statistical Process Co.).

XANES/EXAFS spectra were collected at Wiggler 17C1 beam line of Taiwan National Synchrotron Radiation Research Center (NSRRC). The electron storage ring was operated with the energy of $1.5 \mathrm{GeV}$ and a current of 100-200 mA. A Si(111) double crystal monochromator (DCM) was used for providing highly monochromatized photon beams with energies of 1 to $15 \mathrm{keV}$. The double crystal monochromators employing at selected X-rays with energy resolving power $(E / \Delta E)$ better than 7000 , sufficient for most XAS measurements. Data were collected in fluorescence or transmission mode with a Lytle ionization detector (Lytle, 1999) in the region of the $\mathrm{Cu}$ (8979 eV) for K edge experiments at room temperature. The EXAFS function was derived from the raw absorption data through the pre-edge and post-edge background subtraction and then normalized with respect to the edge jump by using program package AUTOBK. After being $k^{2}$-weigted $\left(k\right.$-range $\left.=2.5-12.5^{-1}\right)$, where $k$ is the photoelectron wavenumber, the EXAFS function was Fourier transformed from $k$-space to $r$-space. Local structural pa-
Table 1 A typical composition of commercial gasoline or diesel fuel in Taiwan

\begin{tabular}{lcc}
\hline Parameter & Gasoline & Diesel \\
\hline Boiling range [K] & $315-478$ & $503-622$ \\
Average sulfur content & 76 & 49 \\
[ppmw] & & \\
Aromatics [vol\%] & $30-31$ & $16-17$ \\
Olefins [vol\%] & 1.8 & 5.0 \\
$n$-Alkanes [vol\%] & 17.5 & Nill \\
Available branched alkanes & 32 & Nill \\
[vol\%] & & \\
Cycloalkanes [vol\%] & 5 & Nill \\
Saturates [vol\%] & Not available & 78 \\
\hline
\end{tabular}

Table 2 Breakthrough and saturation loadings of total sulfur from gasoline or diesel fuel on $\mathrm{Cu}(\mathrm{I})-\mathrm{Y}$ zeolite nanoparticles

\begin{tabular}{lcc}
\hline Parameter & Gasoline & Diesel \\
\hline Breakthrough loading $[\mathrm{mg} / \mathrm{g}]$ & 9 & 21 \\
Saturation loading $[\mathrm{mg} / \mathrm{g}]$ & 23 & 36 \\
\hline
\end{tabular}

rameters such as the bond distance $R$, coordination number $N$, and Debye-Waller factor $\sigma$, for different coordination shells surrounding the absorbing atoms were obtained through non-linear least-square fitting routine. All the computer programs were implemented in the software package UWXAFS 3.0 (University of Washington Office of Technology Transfer). The phase shifts and backscattering amplitudes were theoretically calculated by using FEFF 8.20 code based on the crystallographic data of individual species (Zabinsky et al., 1995; Lytle, 1999).

\section{Results and Discussion}

After the activation of $\mathrm{Cu}(\mathrm{I})-\mathrm{Y}$ zeolite sorbent, desulfurization of commercial gasoline (76 ppmw S) and diesel (49 ppmw S) were performed by $\pi$-complexation ion-exchange in a fixed-bed adsorber conducted at ambient temperature and pressure. The composition of commercial gasoline and diesel were analyzed shown in Table 1 and the results showed that average sulfur content of gasoline was 76 ppmw and 49 ppmw of diesel.

Breakthrough adsorption curves of gasoline and diesel fuel on $\mathrm{Cu}(\mathrm{I})-\mathrm{Y}$ zeolite adsorbents were generated using plotting the transient total sulfur concentration normalized by the feed total sulfur concentration versus cumulative fuel volume normalized by total adsorbent weight. The adsorption amounts (normalized per adsorbent weight) were obtained after integrating for the areas above the breakthrough curves. The total sulfur concentrations in the fixed-bed adsorber effluent were monitored periodically as a function of time. Table 2 summarized that the $\mathrm{Cu}(\mathrm{I})-\mathrm{Y}$ zeolite had higher thiophenic sulfur removal capacity ( $\sim 36 \mathrm{mg} / \mathrm{g})$ from diesel liquid fuels. Sim- 


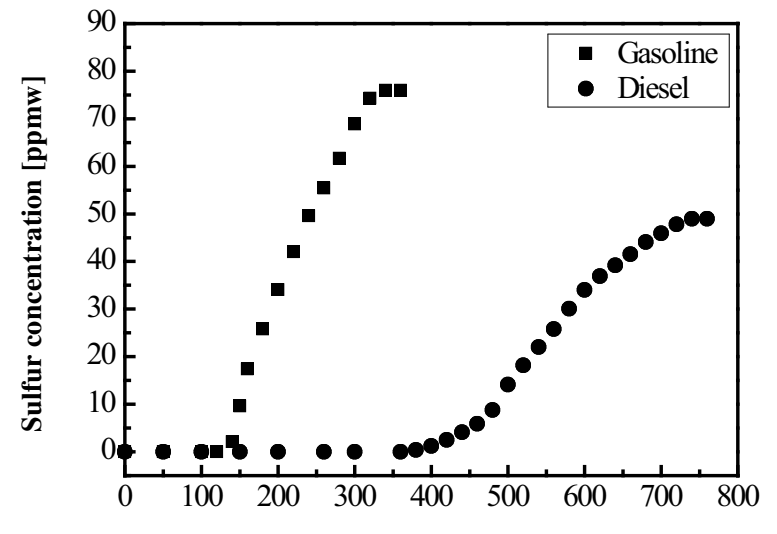

Cumulative effluent volume/weight of adsorbent $[\mathrm{mL} / \mathrm{g}]$

Fig. 1 Breakthrough of total sulfur in a fixed-bed adsorber: $\mathrm{Cu}(\mathrm{I})-\mathrm{Y}$ zeolite nanoparticle for the commercial gasoline and diesel feed using fresh activated $\mathrm{Cu}(\mathrm{I})$ Y zeolite nanoparticles at $298 \mathrm{~K}$ and 1 atm (initial total sulfur concentration: commercial gasoline (76 ppmw) and diesel (49 ppmw)

ilarly, high sulfur removal capacity ( $\sim 23 \mathrm{mg} / \mathrm{g}$ ) was also found for commercial gasoline. The adsorption amounts (normalized per adsorbent weight) were obtained after calculating the integrated equation based on the value of area above the breakthrough curves at any time $t$ (Seader and Henley, 1998).

Figure 1 showed that the total sulfur breakthrough curve obtained during treatment of the commercial gasoline and diesel using fresh activated $\mathrm{Cu}(\mathrm{I})-\mathrm{Y}$ zeolite nanoparticles at $298 \mathrm{~K}$ and $1 \mathrm{~atm}$. The sulfur concentrations of effluent fuel liquids was 4 and $72 \mathrm{ppmw}$ at breakthrough $(145 \mathrm{~mL})$ and saturation $(310 \mathrm{~mL})$ conditions for the commercial gasoline, respectively, while the sulfur concentrations of effluent fuel liquids was 3 and 47 ppmw at breakthrough $(420 \mathrm{~mL})$ and saturation $(720 \mathrm{~mL})$ conditions for the commercial diesel, respectively. The different sulfur compounds in these two fuels may have an effect of the sulfur capacity. However, the sulfur capacity was clearly equilibrium limited, i.e., the saturated sorbents were in equilibrium with the feed solution. The higher total sulfur content in the commercial gasoline (76 ppmw $\mathrm{S}$ ) and diesel (49 ppmw S) resulted in higher sulfur capacities.

As shown in Table 3, GC/FPD results also indicated that the sorbents selectively adsorbed highly substituted thiophenes, benzothiophenes, and dibenzothiophenes from CGDFs. It represented that the major sulfur compounds existing in current CGDFs are the alkyl dibenzothiophenes with one or two methyl groups at 4and 6-positions, which are the refractory sulfur compounds in CGDFs due to the space interference of the methyl groups in HDS process.

The FE-SEM image of $\mathrm{Cu}(\mathrm{I})-\mathrm{Y}$ zeolite has shown in Figure 2(a). It showed a pellet-like shape of $\mathrm{Cu}(\mathrm{I})-\mathrm{Y}$ zeolite nanoparticles formed with diameters of approxi-
Table 3 GC/FPD analyses of typical sulfur compounds/relatives in the fresh commercial gasoline/diesel and the residues of fuels after desulfurization on $\mathrm{Cu}(\mathrm{I})-\mathrm{Y}$ zeolite adsorbents

\begin{tabular}{lll}
\hline $\begin{array}{l}\text { Sulfur compounds } \\
\text { and relatives }\end{array}$ & Gasoline & Diesel \\
\hline Fresh & $\begin{array}{l}\text { Thiophene derivatives: } \\
\text { BT, DBT, 4,6-DMDBT; }\end{array}$ & BT, DBT, \\
& Alkyl derivatives: 4- & 4-MDBT \\
& MDBT & \\
& Trace & Trace \\
After & & \\
\hline
\end{tabular}

mately 50-80 nm. Figure 2(b) also indicated that the ionexchanged $\mathrm{Cu}(\mathrm{I})-\mathrm{Y}$ zeolite nanoparticle was well crystalline but it aggregated in the calcination processes at high temperature (above $700 \mathrm{~K}$ ).

The XRD patterns of $\mathrm{Cu}$ doped $\mathrm{Y}$ zeolite are shown in Figure 3 with sulfur adsorption in different conditions. The XRD spectra showed that the crystal structure of the fresh $\mathrm{Cu}(\mathrm{I})-\mathrm{Y}$ zeolite was changed after sulfur adsorption in gasoline and diesel as the two strong peaks at $2 \theta$ of 35.58 and $38.76^{\circ}$ were disappeared, which indicated that the presence of $\mathrm{CuO}$ in the $\mathrm{Cu}$-doped $\mathrm{Y}$ zeolite catalyst (Massarotti et al., 1998). Furthermore, characteristic peaks at the region of $2 \theta=45$ to $48^{\circ}$ remain identical for $\mathrm{CuO}$. Moreover the adsorbent calcined at $523 \mathrm{~K}$ in air showed some strong new peaks. It might be due to higher order crystal structure formed in higher temperature. But calcined at the same temperature in hydrogen atmosphere did not show these type of peaks represented in Figure 3(a).

The reduction temperature profile for $\mathrm{Cu}(\mathrm{II})-\mathrm{Y}$ zeolite was studied using TPR technique. The experiments were performed using an inert gas containing approximately $30 \mathrm{vol} \%$ hydrogen and a custom-made vertical reactor fitted with a heating jacket. The temperature was increased at $10^{\circ} \mathrm{C} / \mathrm{min}$. The TPR effluent from the bed of the sample was analyzed by a gas chromatograph. The intensity measured by the thermal conductivity detector (TCD) indicated $\mathrm{H}_{2}$ consumption. Figure 4 shows the resulting TPR profile for $\mathrm{Cu}(\mathrm{II})-\mathrm{Y}$ zeolite. The profile shows two major distinct peaks at $462 \mathrm{~K}$ and $509 \mathrm{~K}$. These two peaks corresponded to two reduction steps. The first peak at $462 \mathrm{~K}$ indicated the reduction from $\mathrm{Cu}(\mathrm{II})$ to $\mathrm{Cu}(\mathrm{I})$, while the second peak indicated the reduction from $\mathrm{Cu}(\mathrm{I})$ to copper metal. The difference in intensities of the two peaks was likely caused by incomplete conversion of $\mathrm{Cu}(\mathrm{I})$ to copper metal. From the above result, it was determined that $462 \mathrm{~K}$ was the appropriate temperature for reduction to $\mathrm{Cu}(\mathrm{I})$. Stepwise reduction of $\mathrm{Cu}$ (II) ions in liquid-phase exchanged zeolites and dispersion on activated alumina supports have been reported before (Rouco, 1994; Guidry and Price, 1999; Takahashi 
Table 4 Elemental analysis for $\mathrm{S}$ total content of nanopahse $\mathrm{Cu}(\mathrm{I})-\mathrm{Y}$ zeolite adsorbents at different activated conditions for the commercial gasoline

\begin{tabular}{lc}
\hline Activated condition of adsorbent & Net $\mathrm{S}[\mathrm{mg} / \mathrm{g}]$ \\
\hline Fresh adsorbent before adsorption & 0 \\
In $\mathrm{H}_{2}$ atmosphere and at $523 \mathrm{~K}$ & 5.8 \\
In air and at $523 \mathrm{~K}$ & 16.8 \\
In air and at $393 \mathrm{~K}$ & 8.6 \\
\hline
\end{tabular}
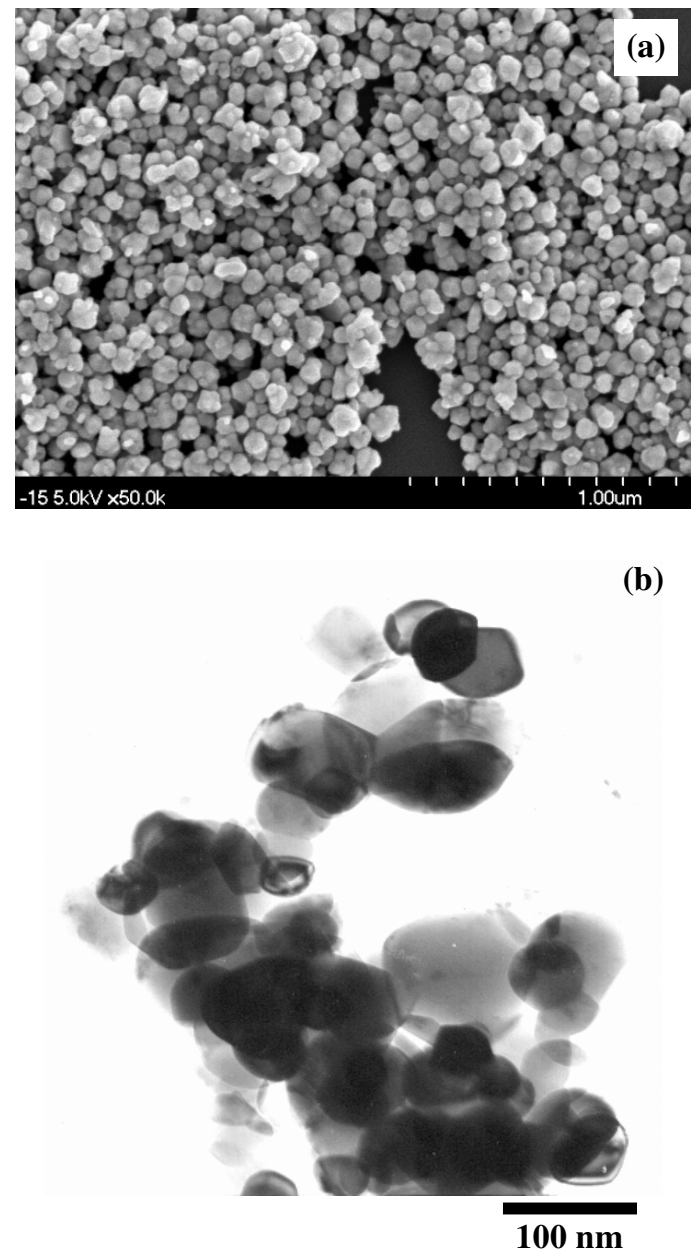

Fig. 2 Image of nanophase $\mathrm{Cu}(\mathrm{I})-\mathrm{Y}$ zeolite adsorbent calcined under a flowing He gas at $723 \mathrm{~K}$ : (a) FE-SEM and (b) TEM

et al., 2000). A reduction temperature of about $462 \mathrm{~K}$ is sufficient to obtain the cuprous species required for $\pi$ complexation.

The results of sulfur elemental analyses of the $\mathrm{Cu}(\mathrm{I})-\mathrm{Y}$ zeolite adsorbent at different activated conditions the commercial gasoline are shown in Table 4. It showed that the sulfur content of $\mathrm{Cu}(\mathrm{I})-\mathrm{Y}$ zeolite was higher under air at $523 \mathrm{~K}$. It also indicated that the sulfur content at same environment but lower temperature (393

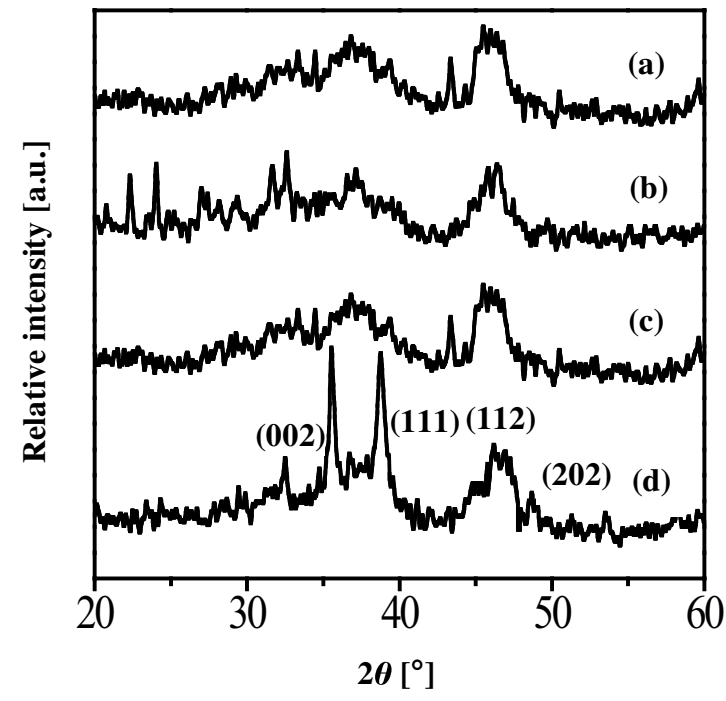

Fig. 3 XRD patterns of $\mathrm{Cu}(\mathrm{I})-\mathrm{Y}$ zeolite adsorbent of (a) reduced under $\mathrm{H}_{2}$ at $523 \mathrm{~K}$, (b) calcined under air at $523 \mathrm{~K}$, (c) calcined under air at $393 \mathrm{~K}$, and (d) the fresh catalyst before calcination used for the desulfurization of CGDFs

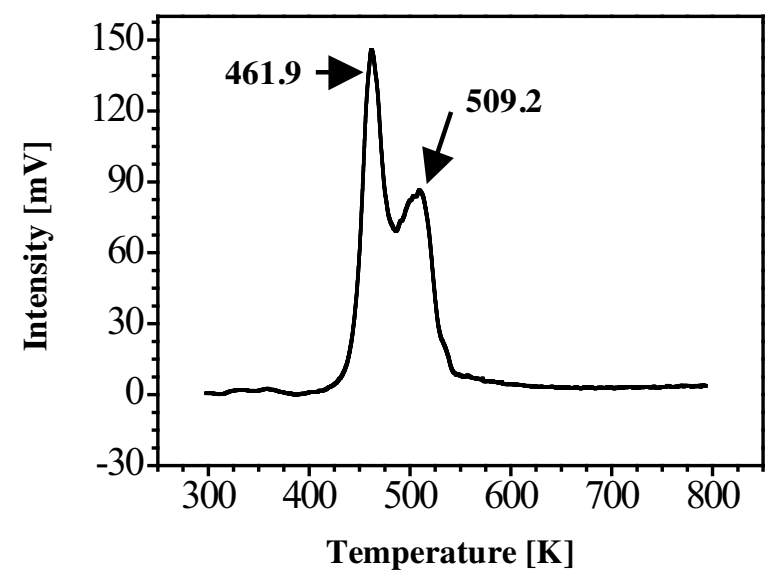

Fig. 4 TPR curve of $\mathrm{Cu}-\mathrm{Y}$ zeolite adsorbent under a flow rate of $30 \mathrm{~mL} / \mathrm{min}$ of $\mathrm{H}_{2} / \mathrm{Ar}$ mixture and a heating rate of $10 \mathrm{~K} / \mathrm{min}$

$\mathrm{K})$ was lower than that of elevated temperature. The net weights of sulfur content of catalyst were 16.8 and 8.6 at 523 and $393 \mathrm{~K}$ respectively at air atmosphere. It might be due to the higher crystal order formed of the Y zeolite adsorbent at elevated temperature and moreover, for the $\pi$-complexation, about $462 \mathrm{~K}$ (from Figure 4) was required. But, $393 \mathrm{~K}$ was not sufficient to convert the $\mathrm{Cu}(\mathrm{II})$ to $\mathrm{Cu}(\mathrm{I})$ state which was the main requirement for the $\pi$ complexation ion exchange. The $\mathrm{Cu}(\mathrm{I})$ ions may be oxidized in the presence of $\mathrm{H}_{2} \mathrm{O}$ or $\mathrm{O}_{2}$ and that the process was accelerated in the simultaneous presence of both oxidative species. This result should apply also for $\mathrm{Cu}-\mathrm{Y}$ zeolite adsorbent, reinforcing the need for proper activation of the zeolites to maintain the maximum possible 


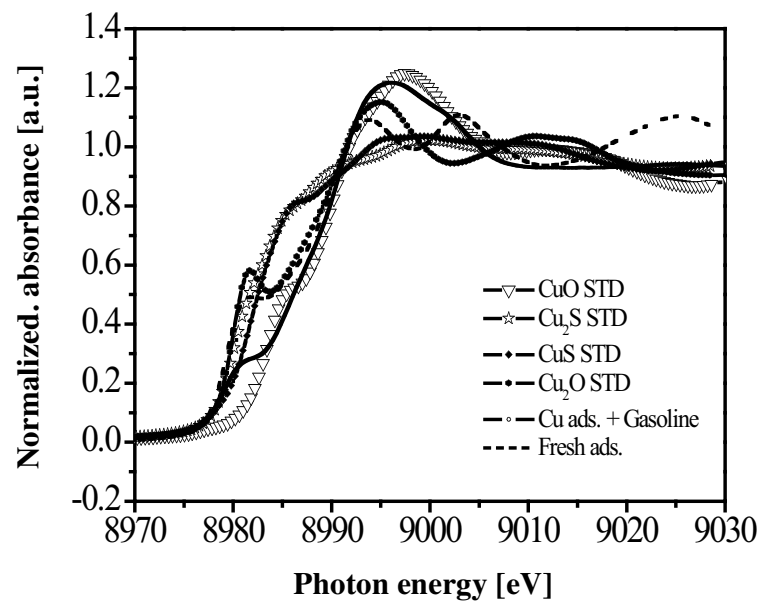

Fig. 5 XANES spectra of fresh activated $\mathrm{Cu}(\mathrm{I})-\mathrm{Y}$ zeolite, sulfur-adsorbed $\mathrm{Cu}(\mathrm{I})-\mathrm{Y}$ zeolite adsorbent, $\mathrm{Cu}_{2} \mathrm{~S}$, $\mathrm{CuS}, \mathrm{Cu}_{2} \mathrm{O}$, and $\mathrm{CuO}$ standards ("ads" denotes "Cu(I)-Y zeolite adsorbent")

amount of $\mathrm{Cu}(\mathrm{I})$ ions before desulfurization processes. Furthermore, the air atmosphere was more favorable for the sulfur adsorption than hydrogen.

For $\mathrm{Cu}(\mathrm{II})-\mathrm{Y}$, the activation was conducted at $723 \mathrm{~K}$ under a flowing $\mathrm{He}$ gas to enhance auto-reduction of $\mathrm{Cu}$ (II) to $\mathrm{Cu}(\mathrm{I})$ species, which is needed for $\pi$ complexation. For sulfur removal using $\pi$-complexation to be successful, it is necessary for the copper to be in the $\mathrm{Cu}(\mathrm{I})$ state. Actually, treatment in dry air, which should yield only $\mathrm{Cu}$ (II) species. Takahashi et al. (2000) found that $\mathrm{Cu}(\mathrm{II})-\mathrm{Y}$ zeolite adsorbents can be auto-reduced in $\mathrm{He}$ gas at $723 \mathrm{~K}$ under moisture free and $\mathrm{O}_{2}$ free conditions. $50 \%$ of the original $\mathrm{Cu}(\mathrm{II})$ ions were reduced to $\mathrm{Cu}(\mathrm{I})$ ions after $1 \mathrm{~h}$ activation process. Therefore, activation time plays a crucial part in obtaining more $\mathrm{Cu}(\mathrm{I})$ species. Lower temperature activation to obtain $\mathrm{Cu}(\mathrm{I})$ ions may not result in the formation of as many $\mathrm{Cu}(\mathrm{I})$ ions either. This results indicated that there were not as many $\mathrm{Cu}(\mathrm{I})$ ions present in the $623 \mathrm{~K} \mathrm{He}$-treated adsorbent as compared to the $723 \mathrm{~K}$ treated adsorbent. It should be noted that, after several hours of auto-reduction, the color of $\mathrm{Cu}(\mathrm{I})-\mathrm{Y}$ zeolite was pale green, compared to a bluish green typically observed in $\mathrm{Cu}(\mathrm{II})-\mathrm{Y}$.

To investigate the structure of the copper species in $\mathrm{Y}$ zeolite, X-ray absorption spectra of the catalyst were also performed. The XANES spectra of $\mathrm{Cu}-\mathrm{Y}$ zeolite for sulfur adsorption from gasoline were represented in Figure 5. The preedge XANES spectrum of $\mathrm{Cu}-\mathrm{Y}$ zeolite exhibits very weak absorbance feature for the $1 \mathrm{~s}$ to $3 \mathrm{~d}$ transition which is forbidden by the selection rule in the case of perfect octahedral symmetry. There is a shoulder at $8981-8983 \mathrm{eV}$ which is due to the dipole-allowed of $1 \mathrm{~s}$ to $4 p_{x y}$ electron transition. It confirms that the existence of $\mathrm{Cu}(\mathrm{I})$ in the catalyst. The intensity of the $1 \mathrm{~s}$ to $4 p_{x y}$ transition is proportional to the amount of $\mathrm{Cu}(\mathrm{I})$ in $\mathrm{Cu}-\mathrm{Y}$
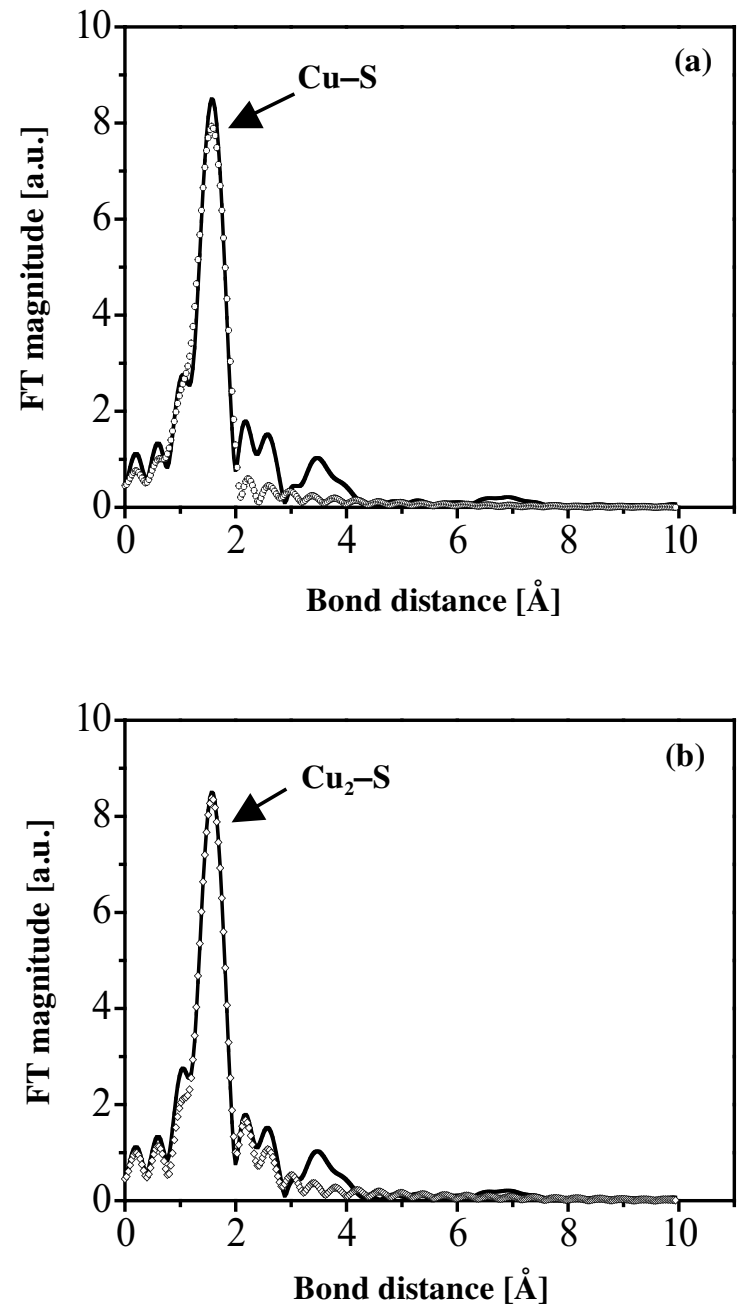

Fig. 6 Fourier transform (FT) spectra of (a) $\mathrm{Cu}$ (II)- and (b) reduced $\mathrm{Cu}(\mathrm{I})-\mathrm{Y}$ zeolite adsorbent calcined under a flowing $\mathrm{He}$ gas at $723 \mathrm{~K}$. The best fitting of the EXAFS spectra are expressed by the dotted lines

zeolite. An intense feature at $8992-8996 \mathrm{eV}$ are attributed to the $1 s$ to $4 p_{x y}$ transition that indicates the existence of $\mathrm{Cu}$ (II) species in $\mathrm{Cu}-\mathrm{Y}$ zeolite. From the XANES spectra, the coexistence of $\mathrm{Cu}(\mathrm{I})$ and $\mathrm{Cu}(\mathrm{II})$ in the $\mathrm{Cu}-\mathrm{Y}$ zeolite was found (Lin and Wang, 1999, 2000a, 2000b).

Generally, Cu K-edge EXAFS spectroscopy can provide the information on the atomic arrangement of sorbents in terms of bond distance, bond angle, coordination number and kind of neighbors. A high reliability of the EXAFS data fitting for $\mathrm{Cu}$ species in $\mathrm{Y}$ zeolite was obtained. The data were collected several times and the standard deviation also calculated from the averaged spectra. The Fourier transformation was performed on $k^{2}$ weighted oscillations over the range of 2.5 and $12.5 \AA^{-1}$.

As shown in Figure 6(a), a central $\mathrm{Cu}$ atom has a $\mathrm{Cu}(\mathrm{II})-\mathrm{S}$ bonding of organosulfur complex with a bond distance of $1.81 \pm 0.05$ and a coordination number of 3.8 in $\mathrm{Cu}(\mathrm{II})-\mathrm{Y}$ zeolite nanoparticles. It is likely that the 
Table 5 Fine structural parameters of $\mathrm{Cu}(\mathrm{I})-\mathrm{Y}$ zeolite adsorbent analyzed by EXAFS

\begin{tabular}{|c|c|c|c|c|}
\hline $\begin{array}{l}\text { Analyzed } \\
\text { item }\end{array}$ & $\begin{array}{c}\text { Bonding } \\
\text { pair }\end{array}$ & $\mathrm{CN}^{a}$ & $\mathrm{R}^{b}( \pm 0.05)$ & $\Delta \sigma^{2}\left(\AA^{2}\right)$ \\
\hline \multicolumn{5}{|c|}{ Copper standard } \\
\hline $\mathrm{CuO}$ & $\mathrm{Cu}-\mathrm{O}$ & 2.1 & 1.95 & 0.0035 \\
\hline $\mathrm{Cu}_{2} \mathrm{O}$ & $\mathrm{Cu}-\mathrm{O}$ & 2.1 & 1.86 & 0.0065 \\
\hline \multicolumn{5}{|c|}{$\mathrm{Cu}$ in fresh $\mathrm{Cu}(\mathrm{I})-\mathrm{Y}$ zeolite (no reduction) } \\
\hline $\mathrm{CuO}$ & $\mathrm{Cu}-\mathrm{O}$ & 3.55 & 1.96 & 0.004878 \\
\hline $\mathrm{Cu}_{2} \mathrm{O}$ & $\mathrm{Cu}-\mathrm{O}$ & 3.58 & 1.96 & 0.004894 \\
\hline \multicolumn{5}{|c|}{ Doped $\mathrm{S}$ in $\mathrm{Cu}(\mathrm{I})-\mathrm{Y}$ zeolite (reduction) } \\
\hline $\mathrm{Cu}$ & $\mathrm{Cu}-\mathrm{Cu}$ & 5.29 & 2.48 & 0.014726 \\
\hline $\mathrm{CuS}$ & $\mathrm{Cu}-\mathrm{S}$ & 1.64 & 2.39 & 0.005548 \\
\hline sulfur & $\mathrm{S}-\mathrm{S}$ & 1.47 & 2.27 & 0.006792 \\
\hline \multicolumn{5}{|c|}{$\mathrm{Cu}(\mathrm{I})-\mathrm{Y}$ zeolite with adsorbed $\mathrm{S}$} \\
\hline $\mathrm{CuS}$ & $\mathrm{Cu}-\mathrm{S}$ & 1.85 & 2.47 & 0.001411 \\
\hline $\mathrm{Cu}_{2} \mathrm{~S}$ & $\mathrm{Cu}-\mathrm{S}$ & 3.04 & 2.35 & 0.009419 \\
\hline
\end{tabular}

Notes: ${ }^{a}$ Coordination number; ${ }^{b}$ Bond distance; ${ }^{c}$ DebyeWaller factor

$\mathrm{Cu}(\mathrm{II})-\mathrm{Y}$ zeolite was formed in ion-exchanging process with $0.5 \mathrm{M} \mathrm{Cu}\left(\mathrm{NO}_{3}\right)_{2(a q)}$ for $48 \mathrm{~h}$. More Interestingly, using EXAFS spectra, the $\mathrm{Cu}(\mathrm{I})-\mathrm{S}$ organosulfur species possess a $\mathrm{Cu}(\mathrm{I})-\mathrm{S}$ bond distance of $1.98 \AA$ with a coordination number of 1.2 shown in Figure 6(b). This result may offer a further explanation of an autoreduction of $\mathrm{Cu}(\mathrm{II})$ to $\mathrm{Cu}$ (I) which was found under a flowing inert $\mathrm{He}$ gas at a higher temperature of $723 \mathrm{~K}$.

The structural parameters of the copper oxide, copper sulfide clusters obtained from the best fit to the EXAFS data are shown in Table 5. The Debye-Waller factors $\left(\Delta \sigma^{2}\right)$ in all EXAFS data were less than $0.015 \AA$. The standard $\mathrm{Cu}-\mathrm{O}$ bond distances in $\mathrm{CuO}$ and $\mathrm{Cu}_{2} \mathrm{O}$ were 1.95 and $1.86 \AA$, respectively with the coordination number of 2.1 in both cases. In the fresh $\mathrm{Cu}(\mathrm{I})-\mathrm{Y}$ zeolite $\mathrm{Cu}-\mathrm{O}$ bond distances in $\mathrm{CuO}$ and $\mathrm{Cu}_{2} \mathrm{O}$ are very much similar to that of standard bond distance $(1.96 \AA)$ but with the different coordination numbers 3.55 and 3.58 , respectively.

After doping sulfur on the $\mathrm{Cu}(\mathrm{I})-\mathrm{Y}$ zeolite the $\mathrm{Cu}-$ $\mathrm{Cu}$ and $\mathrm{Cu}-\mathrm{S}$ bond distances were found 2.48 and 2.39 and the coordination numbers were 5.29 and 1.64 , respectively. After adsorbing sulfur from the gasoline the $\mathrm{Cu}-\mathrm{S}$ bond distances in $\mathrm{CuS}$ and $\mathrm{Cu}_{2} \mathrm{~S}$ were 2.47 and $2.35 \AA$ with the coordination number 1.85 and 3.04, respectively. It showed that the bond distance of $\mathrm{Cu}-\mathrm{S}$ increased with adsorption of sulfur on to the copper surface and predominated that $\mathrm{Cu}-\mathrm{O}$ and $\mathrm{Cu}-\mathrm{Cu}$ are the main oxidation active sites in the $\mathrm{Y}$ zeolite channels for the adsorption of sulfur.

\section{Conclusions}

This work has demonstrated that copper-exchanged Y-type zeolites are excellent adsorbents for the removal of thiophene from gasoline and diesel fuel, based on fixed bed adsorption. It was capable of reducing the sulfur content to lower values for long periods of time. $\mathrm{Cu}(\mathrm{I})-\mathrm{Y}$ zeolite provided the best adsorption capacity both at breakthrough point and at saturation. Our experimental results, demonstrate that organic sulfur compounds in gasoline and diesel fuel can be removed by selective adsorption using a transition metal compound loaded on a porous support. More studies will be needed in order to fully understand the effect of copper loading and the relation between copper and sulfur include thiophenes, which are abundant in commercial liquid fuels.

\section{Literature Cited}

Al-Shahrani, F., T. Xiao, S. A. Llewellyn, S. Barri, Z. Jiang, H. Shi, G. Martinie and M. L. H. Green; "Desulfurization of Diesel via the $\mathrm{H}_{2} \mathrm{O}_{2}$ Oxidation of Aromatic Sulfides to Sulfones Using a Tungstate Catalyst," Appl. Catal., B, 73, 311-316 (2007)

Babich, I. V. and J. A. Moulijn; "Science and Technology of Novel Processes for Deep Desulfurization of Oil Refinery Streams: A Review," Fuel, 82, 607-631 (2003)

Baeza, P., G. Aguila, F. Gracia and P. Araya; "Desulfurization by Adsorption with Copper Supported on Zirconia," Catal. Commun., 9, 751-755 (2008)

Bhandari, V. M., C. H. Ko, J. G. Park, S. S. Han, S. H. Cho and J. N. Kim; "Desulfurization of Diesel Using Ion-Exchanged Zeolites," Chem. Eng. Sci., 61, 2599-2608 (2006)

Caero, L. C., F. Jorge, A. Navarro and A. Gutiérrez-Alejandre; "Oxidative Desulfurization of Synthetic Diesel Using Supported Catalysts Part II. Effect of Oxidant and Nitrogen-Compounds on ExtractionOxidation Process," Catal. Today, 116, 562-568 (2006)

García-Gutiérrez, J. L., G. A. Fuentes, M. E. Hernández-Terán, P. García, F. Murrieta-Guevara and F. Jiménez-Cruz; "Ultra-Deep Oxidative Desulfurization of Diesel Fuel by the $\mathrm{Mo} / \mathrm{Al}_{2} \mathrm{O}_{3}-\mathrm{H}_{2} \mathrm{O}_{2}$ System: The Effect of System Parameters on Catalytic Activity," Appl. Catal., A, 334, 366-373 (2008)

Guidry, T. F. and G. L. Price; "The Conversion of 1-Propanamine on Copper-Containing MFI and BEA Zeolites Prepared by Aqueous and Vapor Ion-Exchange," J. Catal., 181, 16-27 (1999)

Hernández-Maldonado, A. J. and R. T. Yang; "Desulfurization of Liquid Fuels by Adsorption via $\pi$-Complexation with $\mathrm{Cu}(\mathrm{I})-\mathrm{Y}$ and $\mathrm{Ag}-\mathrm{Y}$ Zeolites," Ind. Eng. Chem. Res., 42, 123-129 (2003)

Hernández-Maldonado, A. J., F. H. Yang, G. Qi and R. T. Yang; "Desulfurization of Transportation Fuels by $\pi$-Complexation Sorbents: $\mathrm{Cu}(\mathrm{I})-, \mathrm{Ni}(\mathrm{II})-$, and $\mathrm{Zn}(\mathrm{II})-Z$ Zeolites," Appl. Catal., B, 56, 111-126 (2005a)

Hernández-Maldonadoa, A. J., G. Qi and R. T. Yang; "Desulfurization of Commercial Fuels by $\pi$-Complexation: Monolayer $\mathrm{CuCl} / \gamma$ $\mathrm{Al}_{2} \mathrm{O}_{3}$," Appl. Catal., B, 61, 212-218 (2005b)

Kim, J. H., X. Ma, A. Zhou and C. Song; "Ultra-Deep Desulfurization and Denitrogenation of Diesel Fuel by Selective Adsorption over Three Different Adsorbents: A Study on Adsorptive Selectivity and Mechanism," Catal. Today, 111, 74-83 (2006)

Lin, K. S. and H. P. Wang; "Shape Selectivity of Trace By-Products for Supercritical Water Oxidation of 2-Chlorophenol Effected by CuO/ZSM-48," Appl. Catal., B, 22, 261-267 (1999)

Lin, K. S. and H. P. Wang; "Supercritical Water Oxidation of 2Chlorophenol Catalyzed by $\mathrm{Cu}^{2+}$ Cations and Copper Oxide Clusters," Environ. Sci. Technol., 34, 4849-4854 (2000a)

Lin, K. S. and H. P. Wang; "By-Product Shape Selectivity in Supercritical Water Oxidation of 2-Chlorophenol Effected by CuO/ZSM-5," Langmuir, 16, 2627-2631 (2000b)

Lytle, F. W.; "The EXAFS Family Tree: A Personal History of the Development of Extended X-Ray Absorption Fine Structure," J. Synchrotron Radiat., 6, 123-134 (1999)

Ma, X., L. Sun and C. Song; "A New Approach to Deep Desulfurization of Gasoline, Diesel Fuel and Jet Fuel by Selective Adsorption for Ultra-Clean Fuels and for Fuel Cell Applications," Catal. Today, 77, 107-116 (2002) 
Ma, X., S. Velu, J. H. Kim and C. Song; "Deep Desulfurization of Gasoline by Selective Adsorption over Solid Adsorbents and Impact of Analytical Methods on ppm-Level Sulfur Quantification for Fuel Cell Applications," Appl. Catal., B, 56, 137-147 (2005)

Massarotti, V., D. Capsoni, M. Bini, A. Altomare and A. G. G. Moliterni; "X-Ray Powder Diffraction ab initio Structure Solution of Materials from Solid State Synthesis: The Copper Oxide Case," Z. Kristallogr., 213, 259-265 (1998)

Mikhail, S., T. Zaki and L. Khalil; "Desulfurization by an Economically Adsorption Technique," Appl. Catal., A, 227, 265-278 (2002)

Rouco, A. J.; "TPR Study of $\mathrm{Al}_{2} \mathrm{O}_{3}$ - and $\mathrm{SiO}_{2}$-Supported $\mathrm{CuCl}_{2}$ Catalysts," Appl. Catal., A, 117, 139-149 (1994)

Salem, A. B. S. H.; "Naphtha Desulfurization by Adsorption," Ind. Eng. Chem. Res., 33, 336-340 (1994)

Schulz, H., W. Böhringer, P. Waller and F. Ousmanov; "Gas Oil Deep Hydrodesulfurization: Refractory Compounds and Retarded Kinetics," Catal. Today, 49, 87-97 (1999)

Seader, J. D. and E. J. Henley; Separation Process Principles, Wiley, New York, U.S.A. (1998)

Song, C.; "An Overview of New Approaches to Deep Desulfurization for Ultra-Clean Gasoline, Diesel Fuel and Jet Fuel," Catal. Today, 86, 211-263 (2003)

Takahashi, A., F. H. Yang and R. T. Yang; "Aromatics/Aliphatics Separation by Adsorption: New Sorbents for Selective Aromatics Adsorption by $\pi$-Complexation," Ind. Eng. Chem. Res., 39, 3856-
3867 (2000)

Tang, K., L. J. Song, L. H. Duan, X. Q. Li, J. Z. Gui and Z. L. Sun; "Deep Desulfurization by Selective Adsorption on a Heteroatoms Zeolite Prepared by Secondary Synthesis," Fuel Process. Technol., 89, 1-6 (2008)

Velu, S., X. Ma and C. Song; "Selective Adsorption for Removing Sulfur from Jet Fuel over Zeolite-Based Adsorbents," Ind. Eng. Chem. Res., 42, 5293-5304 (2003)

Wang, H. C., H. P. Wang and K. S. Lin; "Adsorption of Pyridine on Dealuminated Zeolite HY," J. Environ. Sci. Health, Part AToxic/Hazard Subst. Environ. Eng., A34, 1849-1858 (1999)

Xue, M., R. Chitrakar, K. Sakane, T. Hirotsu, K. Ooi, Y. Yoshimura, M. Toba and Q. Feng; "Preparation of Cerium-Loaded Y-Zeolites for Removal of Organic Sulfur Compounds from Hydrodesulfurizated Gasoline and Diesel Oil," J. Colloid Interface Sci., 298, 535542 (2006)

Yang, R. T., A. Takahashi and F. H. Yang; "New Sorbents for Desulfurization of Liquid Fuels by $\pi$-Complexation," Ind. Eng. Chem. Res., 40, 6236-6239 (2001)

Yang, R. T., A. J. Hernández-Maldonado and F. H. Yang; "Desulfurization of Transportation Fuels with Zeolites under Ambient Conditions," Science, 301, 79-81 (2003)

Zabinsky, S. I., J. J. Rehr, A. Ankudinov, R. C. Albers and M. J. Eller; "Multiple-Scattering Calculations of X-Ray Adsorption Spectra," Phys. Rev. B: Condens. Matter, 52, 2995-3009 (1995) 